\title{
The euro and the recent European crisis vis-à- vis the gold standard and the great depression: institutionalities, specificities and interfaces
}

\author{
O euro e a crise europeia recente vis-à-vis o padrão ouro e a grande \\ depressão: institucionalidades, especificidades e interfaces
}

GIULIANO CONTENTO DE OLIVEIRA

PAULO JOSÉ WHITAKER WOLF*

\begin{abstract}
RESUMO: O artigo busca estabelecer interfaces entre a Grande Depressão dos anos 1930 sob o Padrão Ouro e a Crise Europeia recente sob o Euro. Argumenta-se que, a despeito de suas especificidades, as duas crises revelaram os efeitos potencialmente nocivos, em termos econômicos e sociais, de arranjos institucionais que reduzem consideravelmente a autonomia das políticas monetária, fiscal e cambial dos países participantes, sem, entretanto, serem acompanhados pelo aumento da cooperação liderado por uma potência hegemônica, em âmbito global (no caso da Grande Depressão) ou regional (no caso da Crise Europeia), que não apenas seja capaz, mas que também esteja disposta a exercer as funções de comprador e emprestador de última instância, sobretudo em momentos caracterizados pelo aumento da incerteza, pela deterioração do estado geral das expectativas e pelo aumento da preferência pela liquidez. De fato, tanto os países do centro europeu no passado como os países da periferia europeia no período recente foram efetivamente empurrados em direção a ajustes deflacionários em que a redução de preços e salários foi acompanhada pela redução da produção e do emprego. Assim, na ausência da possibilidade de se restaurar a autonomia de política econômica, a superação da crise pressupõe, tanto antes - sob o padrão ouro - como atualmente - sob o Euro -, ações conjuntas destinadas a assegurar que a responsabilidade do ajuste seja distribuída igualmente entre as economias e que, portanto, algumas delas não sejam beneficiadas à custa de outras nesse processo.

PALAVRAS-CHAVE: padrão ouro; grande depressão; crise europeia; euro.
\end{abstract}

ABSTRACT: The paper aims to establish interfaces between the Great Depression of the 1930s under the Gold Standard and the recent European Crisis under the Euro. It is argued that, despite their specificities, both crises revealed the potentially harmful effects, in economic and social terms, of institutional arrangements that considerably reduce the

\footnotetext{
* Professor do Instituto de Economia da Universidade Estadual de Campinas (IE/Unicamp). E-mail: giulianoliveira@gmail.com. Doutorando em economia no IE/Unicamp.E-mail: paulowwolf@gmail.com. Submitted: 1/June/2015; Approved: 24/February/2016.
} 
autonomy of monetary, fiscal and exchange rate policies of participating countries, without being accompanied by increased cooperation between them, which should be led by a global (in the case of the Great Depression) or regional (in the case of the European Crisis) hegemonic power, which is not only capable of, but is also willing to act as a buyer and lender of last resort, especially in circumstances characterized by increased uncertainty, the deterioration of the general state of expectations and increased liquidity preference. In fact, central European countries in the past and peripheral European countries nowadays were effectively pushed toward deflationary adjustments in which a reduction of prices and wages was accompanied by a reduction of output and employment levels. Thus, in the absence of the possibility of restoring the autonomy of economic policy, the overcome of the crisis necessarily requires, both before - under the Gold Standard - and nowadays - under the Euro -, joint actions aimed to assure that the responsibility for the adjustment will be equally distributed among all the economies, in order to avoid that some of them benefit at the expense of the others in this process.

KEYWORDS: gold standard; great depression; European crisis; euro.

JEL Classification: F50; F55; N10.

\section{INTRODUCTION}

The outbreak of the European crisis in 2008 revealed the destabilizing potential of liberalized and deregulated finances. Under the almost instantaneous contagious effect of the bankruptcy of the American investment bank Lehman Brothers in September 2008 due to the vast and growing interconnection among financial systems, many European countries faced difficulties only comparable to the context of the Great Depression of the 1930's. The sharp retraction of GDP and employment levels, as well as of international trade, were some of the main marks left by both crises.

Thus, the purpose of this paper is to analyze the recent European crisis considering the limitations imposed by the institutionality of the Euro over the economic policy of Eurozone countries, establishing a comparison to the institutionality of the British gold standard and its respective role in the Great Depression of the 1930's from a historical-structural approach. ${ }^{1}$ It is important to observe that these monetary standards correspond to a set of rules, and conventions that governs the monetary and financial relationships within each of these institutionalities.

In both cases, the loss of autonomy over economic policy, accompanied by a modest international cooperation system, contributed to the imposition of a severe deflationary adjustment during those periods characterized by a radical increase of uncertainty. The analysis suggests that the recent European crisis makes the

\footnotetext{
${ }^{1}$ The historical-structural approach seeks to analyze the transformation, in time, of economic, social, and political structures that characterize reality. Therefore, it seeks to match the theoretical, historical, empirical, and quantitative analysis. See Missio, Jayme Jr., and Oreiro (2015).
} 
cooperation between countries of the region a crucial element to enable macroeconomic adjustment alternatives to a recession.

This paper is organized into three sections, in addition to this introduction and the conclusion. Firstly, the main characteristics of the British gold standard that prevailed between 1819 and 1914 and that was restored in the 1920 's ${ }^{2}$, as well as the obstacles imposed by this arrangement to the recovery of the European economies in the context of the Great Depression, are discussed. Subsequently, the main characteristics of the institutionality of the Eurozone and the way they contributed to the depth of the recent crisis are analyzed. Finally, both experiences are compared in light of selected data and indicators.

\section{THE GOLD STANDARD AND THE GREAT DEPRESSION OF THE 1930’S}

The gold standard in place during the Pax Britannica from 1819 to 1914 and, especially, between 1870 and 1914, was effectively a British gold standard, considering the British productive, commercial, and financial hegemonies, in a context of progressive development of a fiduciary currency (Triffin, 1972). The faculty of issuing the main currency of the international monetary system assured England greater flexibility than other countries during those periods characterized by high instability, as the latter, in contrast to the former, were obligated to defend their reserves with the purpose of preserving the credibility of the convertibility system. To all countries, except the country that issued the international currency, the institutionality of the British gold standard imposed (at least, to some degree) a deflationary adjustment in adverse contexts. ${ }^{3}$

After adopting the gold standard, countries were committed to purchasing and selling gold at a specific price in terms of their own currencies (Kenwood and Lougheed, 1992). England was the first country to adopt the gold standard, in the first half of 19th century. Up to the end of that century, most European countries had followed the English example. This was a consequence of the fact that spreading the monetary standard adopted by the hegemonic country to other countries facilitated their access to the most important market for goods and services and assured their access to the deepest and most liquid financial market of the time (Eichengreen, 2000; Polanyi, 1944).

On different occasions, Keynes proposed that a deflationary adjustment induced by the defense of international reserves had an extremely harmful impact on economies. In his opinion, since their central objective was to keep the convertibi-

\footnotetext{
${ }^{2}$ According to Eichengreen (2000, p.78), a little more than forty-five countries had adopted the gold standard by 1931. In 1937, all of them had abandoned this system.

${ }^{3}$ The British gold standard implied a stricter institutionality than the one that prevailed later, under the edge of the gold-dollar standard between 1945 and 1971, in the context of American hegemony. See Eichengreen (2000, p.76).
} 
lity to a fixed parity, the gold standard functioned as a "straitjacket" that avoided the conception and the implementation of autonomous economic policies oriented toward full employment (Keynes, 1930). Furthermore, Keynes (1930) claimed that the process of adjustment of the balance of payments under the gold standard was clearly asymmetrical because it fundamentally fell on deficit countries through a recession and, consequently, a decrease of prices and wages. According to him, due to the impossibility to appeal to a devaluation of exchange rates and to the cost of a deflationary adjustment, the reciprocity in the process of adjustment of the balance of payments among surplus and deficit countries was clearly the wisest alternative available.

In fact, before World War I, the adoption of cooperation measures among countries that adopted the gold standard with the explicit objective of avoiding the collapse of the monetary standard was not unusual. Such initiatives were often led by the hegemonic country of the time, England, and oriented towards increasing the international reserves of central banks of economies in distress in order to assure their credibility and, as a consequence, to avoid their exit of the monetary standard. Therefore, Eichengreen (2000, p.63) claims that:

This kind of international cooperation, while not an everyday event, was critical in times of crisis. It belies the notion that the gold standard was an atomistic system. Rather, its survival depended in collaboration among central banks and governments.

Moreover, as demonstrated by Kindleberger $(1986,1989)$, there was at that time a country not only able, but also willing to take responsibility for the stability of the system by carrying out two main functions, namely: i) to assure a market for goods and services of other countries whenever this market was required (the role of purchaser of last resort); and ii) to assure liquidity for other countries whenever such liquidity was required (the role of lender of last resort). By executing these two main functions, England was able to assure the prevalence of the British gold standard for an extensive period, despite the rigidities of this institutionality for participating countries.

Obviously, this cooperation under English leadership did not seek to avoid recession in countries where the deflationary adjustment was sufficient to restore the credibility of the monetary standard, or enable the adoption of countercyclical economic policies by national governments. Furthermore, this cooperation was limited to central countries, as peripheral countries did not endanger the maintenance of the gold standard. Therefore, many Southern European and Latin American countries, for instance, had to bear severe deflationary adjustments or to suspend convertibility and devaluate their currencies during periods characterized by adversities (Eichengreen, 2000).

Therefore, there were two interconnected pillars that supported the British gold standard, namely: i) the credibility deposited by the market in the capacity of national states to assure the convertibility of their currencies in gold at a fixed ra- 
te; ii) the cooperation among countries that adopted the British gold standard, led by the hegemonic country of this system with the purpose of enabling its proper operation and, thus, of providing the usufruct of its positive externalities (Kindleberger, 1986, 1989; Eichengreen, 2000).

The British gold standard was suspended in Europe after World War I, as the conflict destroyed the pillars that supported this monetary standard, which depended on singular geopolitical conditions. Most European countries restored the old system in the 1920's, believing it would be possible to preserve the status quo ante. Nevertheless, after the end of the conflict, the conditions that prevailed at the end of the $19^{\text {th }}$ century and at the beginning of the $20^{\text {th }}$ century no longer existed. Thus, those countries faced great difficulties to maintain it. To Eichengreen (2000), this was a consequence of the fact that countries had less freedom to not comply with the "rules of the game" ${ }^{4}$ without endangering the credibility and, consequently, the maintenance of the system. For him, the costs of contractionist economic policies oriented towards supporting the gold standard were no long feasible due to the expansion of political and social rights after the conflict. To Triffin (1972), the difficulty in restoring the British gold standard after World War I resulted from the progressive difference between the amount of money and gold available, in view of the progressive expansion of the fiduciary currency system. ${ }^{5}$ To Medeiros and Serrano (1999), the failure of the attempt to return to this system was a result of the loss of industrial competitiveness of England and of changes in international conditions that once allowed its support. Naturally, such explanations can be considered as being complementary.

It is clear that the fragilization of the cooperation among countries certainly had an important role in making the restoration of the British gold standard after World War I impracticable. This was mostly due to the vacuum of hegemony within international relations that prevailed at the time. To Kindleberger (1986, 1989), after World War I, England was no longer able to be responsible for the stability of the international monetary system, whereas the United States was not willing to do so. It created an empty space that significantly contributed to the difficulties of the 1920's and to the Great Depression of the 1930's (Mazzucchelli, 2009).

In fact, the situation worsened after the last quarter of 1929, with the collapse

\footnotetext{
${ }^{4}$ They were: i) a rule setting forth the amount of currency in circulation and storage of gold the country had in order to assure the convertibility, a condition that would contribute to limit the assumption of high and persistent deficits in the current transactions account of the balance of payments by a certain country; ii) freedom to export or to import gold; and iii) a commitment with the maintenance of convertibility of national currency in gold at the fixed exchange rate.

5 This is the notion behind the "Triffin Dilemma". On one hand, upon incurring deficits in external accounts, the issuing country of the international main currency assures the provision of the liquidity required to expand international trade and investment. On the other hand, it endangers the maintenance of the convertibility system and, consequently, the prevailing monetary standard as a consequence of the growing unbalance between the quantity of money in circulation and the amount of gold available.
} 
of the New York Stock Exchange and its consequences in Europe. In the absence of an international cooperation system, countries were forced to adopt rigorous contractionist economic policies, making the economic, social, and political crises even worse. Only after leaving the gold standard could they adopt countercyclical economic policies and embark on a recovery path, which was consolidated with the expenses induced by World War II. In addition to the use of monetary and fiscal policies, most of the countries opted to devaluate their exchange rates and to adopt protectionist commercial policies. However, these policies are questionable in the extent that they presuppose that the gain of one is the loss of another, further hindering the effort of joint recovery (Keynes, 1936).

In this regard, the case of United Kingdom is rather illustrative. In 1925, the British restored the convertibility of the pound in gold at the rate that prevailed before the war. This meant an over-valued exchange rate, which exacerbated the growing unbalances in the British balance of payments and required the maintenance of a rigorous deflationary adjustment, with serious consequences in terms of output, income, and employment, as alerted by Keynes (1925). The return to the gold standard led to the prostration of the British economy throughout the 1920's, especially after the 1929 crisis. The attempt to defend the reserves and, thus, the convertibility in that adverse context, made the economic, social, and political costs unbearable, leading the United Kingdom to abandon the gold standard and to devaluate the pound in 1931. The British decision certainly ended up quickening the abandonment of this system by other countries. ${ }^{6}$

Therefore, the institutionality of the British gold standard imposed to the participating countries the deflationary adjustment as a consequence of its strictness. It could survive while the credibility of the markets in this system and the cooperation among the main countries reminded strong. When the cooperation became no longer possible, the entire system fell apart.

\section{THE EURO AND THE RECENT EUROPEAN CRISIS}

In the years that followed the end of World War II, European countries took the first steps towards what would become the most audacious regional integration project in history. In 1951, the Treaty of Paris created the European Coal and Steel Community, which was responsible for controlling the production and trade of essential resources to the reconstruction of the economies of its member countries. In 1957, the Treaty of Rome created the European Economic Community, a customs union, and the European Atomic Energy Community, which was responsible for increasing cooperation in the nuclear field. In 1965, the three communities began to share the same executive, legislative and judiciary institutions within the European Community, created by the Treaty of Brussels. In 1985, after a pe-

\footnotetext{
${ }^{6}$ Other experiences are also remarkable, such as that of France and Germany. See Mazzucchelli (2009).
} 
riod of modest advances, preparations were initiated for the creation of a common market through the elimination of all remaining barriers to the free movement of goods, services, people, and capital. ${ }^{7}$ The Single European Act of 1986 assured the required institutional changes for that. In 1992, the Maastricht Treaty created the European Union, which was responsible for improving cooperation among member countries, not only in the economic dimension, but also in the social and political dimensions. The Maastricht Treaty was amended by the Treaty of Amsterdam in 1997, by the Treaty of Nice in 2001, and by the Treaty of Lisbon in 2007 (Oliveira, Deos, and Wolf, 2014).

It is important to emphasize the shift of conception of the European regional integration project over time. Originally oriented towards fostering the reconstruction and the economic, social, and political modernization in an adverse context through international cooperation, the European project became, with time, more associated with the conventional conception about what a regional integration project should be - namely, a second-best initiative oriented towards intensifying the flows of goods, services, and capital among different countries of a region through the acceleration of trade and the processes of financial liberalization and deregulation (Raimundo, 2011).

The idea of creating a common currency existed since the beginning of the European regional integration process. In fact, different arrangements were created to assure the stability of exchange rates among European currencies after the collapse of the Bretton-Woods arrangement. ${ }^{8}$ But it was only at the end of the 1980 's and the beginning of the 1990's that the pressures in favor of a monetary union increased considerably. Following the recommendations of the Delors Report of 1989, the Maastricht Treaty initiated the process that would lead to the creation of a common currency. The coordination between monetary, fiscal, and exchange rate policies of member countries was reinforced and it was decided that those that wished to adopt the common currency must assure the convergence of their inflation rates, long-term interest rates, exchange rates, public deficits, and public debts. This process was concluded in 1999 with the creation of the Euro, which would begin to circulate three years later, in 2002. Currently, nineteen out of the twenty-eight member countries of the EU adopt the Euro. Among the nine remaining member countries, some of them are still not qualified to adopt it, while others opted to preserve their old currencies. ${ }^{9}$

\footnotetext{
${ }^{7}$ In a "customs union", the participating countries eliminate the existing barriers to free movement of goods and services among themselves and adopt a common commercial policy with regard to nonparticipant countries. In the "common market", the participating countries also eliminate the existing barriers to the circulation of people and capital, which requires greater coordination among their policies.

8 This is the case of the "European snake", created in 1917, and the "European Monetary System", created in 1979. In practice, in both cases, the European countries were subject to guidelines of Germany's economic policy. See Eichengreen (2000).

${ }^{9}$ The countries that adopt the Euro are: Germany, Austria, Belgium, Cyprus, Slovakia, Slovenia, Spain,
} 
The European countries that opted to adopt the Euro no longer have autonomy over their economic policies. The monetary and exchange rate policies became the responsibility of the European Central Bank, an independent institution whose central objective is to maintain a low and stable inflation rate by handling the short-term interest rate. ${ }^{10}$ On the other hand, the fiscal policy remained a responsibility of national governments, but it was subjected to the rules of the Stability and Growth Pact. The agreement requires the commitment of member countries with budgetary discipline throughout the business cycle, avoiding public deficits above $3 \%$ of GDP and public debts above $60 \%$ of GDP, under penalty of sanctions. These sanctions consist of a non-remunerated deposit, which can be transformed into a fine if the budgetary unbalances are not corrected within the defined term. However, the application of these sanctions is not automatic, and depends on the assessment of the circumstances by the Council of Ministers. With these measures, the fiscal policy was expected to become compatible with the guidelines of the monetary and exchange rate policies defined by the BCE (Arestis and Sawyer, 2011).

In fact, the institutionality of the monetary union indicates that European authorities define their actions considering the behavior of nominal variables. From the conventional point of view, the notion that prevails is that monetary policy must be oriented exclusively towards the maintenance of a low and stable inflation rate, while the other instruments of economic policy must be subordinated to it.

After the creation of the common currency, financial institutions, families, and companies from countries of the European periphery benefited from a credit expansion sponsored by central countries ${ }^{11}$, assuming increasingly riskier financial positions. The market attributed to the former the same risk it attributed to the latter, disregarding the fact that these economies were very different from each other. In a certain way, it can be inferred that the lenders adopted the convention that the strongest economies would rescue the weakest ones if needed, in order to assure the survival of the common currency and its institutionality. ${ }^{12}$ As shown in

Estonia, Finland, France, Greece, Ireland, Italy, Latvia, Lithuania, Luxembourg, Malta, Netherlands, and Portugal. The countries that do not adopt the common currency are: Bulgaria, Croatia, Denmark, Hungary, Poland, United Kingdom, Czech Republic, Romania, and Sweden.

${ }^{10}$ Although the Central Bank of Europe does not legally adopt the regime of inflation targets, it can be said that it actually does so, in the extent that it seeks an inflation rate of approximately $2 \%$.

11 As proposed by Dow (1982) and according to the structural characteristics of their economies, the European countries can be classified into central and peripheral ones, considering the reality of the region.

12 According to the data of BIS, between the beginning of 2005 and the beginning of 2008, the exposure of German, French, Dutch, Belgic, and Austrian banks increased, on average, $8.1 \%$ in the case of assets of Greece, $7.1 \%$ of Spain, $7.9 \%$ of Ireland, and $5.9 \%$ of Portugal. However, between the second half of 2008 and the second half of 2013, the exposure of these banks reduced, on average, by $7.0 \%$ in the case of Greek assets, 3.7\% Spanish, 5.3\% Irish, and 5.1\% Portuguese (Belluzzo, 2013). 
Graph 1, the long-term interest rates of countries such as Spain, Greece, Ireland, and Portugal quickly converged towards the long-term interest rates of Germany between 1993 and mid-2008.

Graph 1: Short term interest rates (Eurozone) and long term interest rates (Germany and the PIGS) (\%) - 1993 to 2013

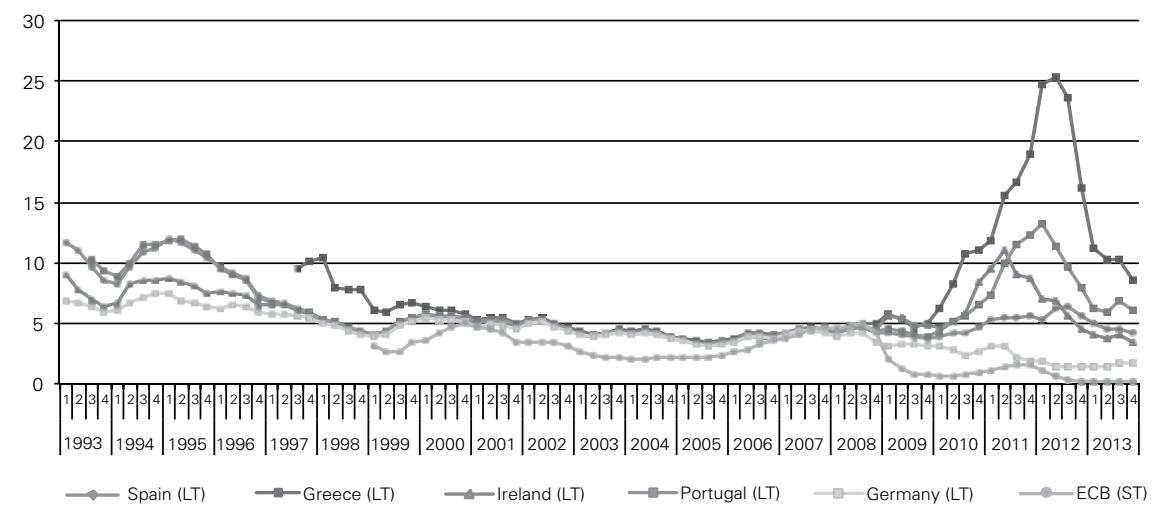

Source: OECD. Elaborated by the authors.

The decisions concerning the allocation of wealth by the economic actors from central countries influence the business cycle of peripheral countries. Although the banks of these countries generally have a smaller relative capacity to finance the expansion of expenditures in advantageous conditions, in terms of volume, costs, and the terms of loans ${ }^{13}$, the purchase of assets of economies of European peripheral countries by investors of central countries encouraged a process of convergence of the interest rates of the economies in the region. For the countries of the European periphery, this movement contributed to extend the liquidity of the financial system and, consequently, to increase the capacity and willingness of the banks of these economies to extend their credit operations. According to Belluzzo (2013, p.12):

[...] the convergence of interest rates and other credit conditions determined a strong flow of capitals to the so-called countries of European periphery, over heating their economies. As a result of monetary union, the competition between German, French, Swede, Austrian and English banks fostered an amazing intra-European 'movement of capitals'. [Our translation]

Nevertheless, after the outbreak of the global crisis in 2008, a sudden interruption of credit from central countries to peripheral countries of the region can

${ }^{13}$ See, for instance, Dow (1987a; 1987b); Chick and Down (1988); Amado and Mollo (2004). 
be observed. Countercyclical interventions from governments followed, leading to the socialization of private losses. However, the increase of their expenditures and the reduction of their receipts led to an increase of public deficits and public debts. In this context, the risk classification agencies reduced the sovereign ratings of the European peripheral countries and the market began to lend to these economies in more unfavorable conditions, also requiring them to implement severe fiscal adjustments (Freitas, 2011).

The fear that governments would not be able to pay their debts was due to the fact that, although these debts were denominated in Euros, these Euros are issued by a supranational institution, the European Central Bank. Because fiscal authorities cannot appeal to the monetary authority for assistance as a measure of last resort, the fear of the conversion of a liquidity crisis into a solvency crisis inevitably spread among the economic actors (De Grawe, 2011).

As shown in Graph 1, after the crisis, the divergence of the long-term interest rates from peripheral countries in relation to the long-term interest rates from central countries and to the short-term interest rates of the Eurozone revealed that there is not only one Euro in the region, but many of them, each reflecting the economic and political importance of the countries that adhered to the monetary union (Oliveira, Deos, and Wolf, 2012). Not even the rescue mechanisms created by the "Troika" (formed by the European Commission, the European Central Bank, and the International Monetary Fund) in mid-2010, to which the peripheral countries would have access only under explicit commitment of advancing in the implementation of a fiscal adjustment, were able to revert the movement of increasing long-term interest rates. In fact, this movement was only contained and subsequently reverted through a more incisive intervention of the European Central Bank in the market, notably after mid-2012.

Furthermore, during the years of credit expansion, the rapid increase of labor costs in the most backward economies of the region, in addition to the relatively weak growth of productivity and to the impossibility of carrying out an autonomous devaluation of exchange rates, led to a competitive disadvantage of peripheral countries in relation to central economies, especially Germany after the labor market reforms carried out by the social-democrat government of Gerhard Schröder in the first half of the 2000's (Bresser, Pereira, and Rossi, 2014). Thus, it is possible to observe an increase of imports compared to exports of peripheral economies and, consequently, a deviation of the already weakened domestic demand to the exterior.

In this context, the countries of the European periphery were induced to make the so-called "structural reforms". ${ }^{14}$ In fact, even in a context of a deep crisis, the governments were pressed to increase receipts and reduce expenses. Simultaneously, The European Central Bank reacted late to reduce the short-term interest rate and, when it did so, it was less aggressive than the central banks of other countries.

${ }^{14}$ Expression designated by the markets for the implementation of liberalization reforms. 
Considering its traditional conservative position, its decision to accept bonds of the most indebted countries of the Eurozone as collateral in its operations with the banking system was really remarkable. It helped revert the falling trajectory of the prices of those papers and, thus, the increasing trajectory of long-term interest rates, thereby reducing pressure on governments of those countries after 2012.

Thus, the crisis required a serious deflationary adjustment from countries of the periphery of the Eurozone, which was similar to the adjustment mechanism of the British gold standard to non-issuing countries of the international currency in adverse situations. As already shown by the ill-fated defense of the gold standard in the 1930's, the attempt to adopt an adjustment of this type in an adverse context contributes to exasperate the crisis and its perverse social effects.

\section{THE EUROPEAN CRISIS UNDER THE EURO AND THE GREAT DEPRESSION UNDER THE GOLD STANDARD}

The limits imposed by the British gold standard to the management of economic policy and its consequences in crises are not very different from those currently introduced by the monetary union in Europe, although there are important differences between both periods, such as the integration degree among the countries participating in these arrangements. This is due to the fact that in the context of the Great Depression of 1930's as well as in the most recent crisis, the European countries were subject to an institutionality that imposes the deflationary adjustment under the reduction of the autonomy over monetary, exchange rate, and fiscal policies, as well as under the absence of a cooperation system between the economies of the region.

With the purpose of analyzing the specificities and interfaces between both periods selected, production and trade indicators for representative countries of the European center and periphery, namely Germany, Italy, United Kingdom, France, and Sweden, on one hand, and Spain, Greece, Ireland, and Portugal, on the other, respectively, were considered. ${ }^{15}$

Table 1 shows the behavior of the GDP of selected European countries between 1928 and 1934, including the context of the Great Depression, as well as between 2007 and 2013, involving the period of recent crisis. ${ }^{16}$ In the majority of the

\footnotetext{
${ }^{15}$ Data on employment and unemployment were not included because they are available only for some selected countries. Moreover, in these cases, there are interruptions in temporal series, the methodologies of different countries are not compatible, and the criteria for data submission do not follow the same standard. For instance, while some countries considered as unemployed those who were looking for a job, others considered as unemployed those who received some form of support in the absence of an occupation. Furthermore, in some cases, the data are related only to the number of people considered unemployed, while in other cases it also considers the ratio between the number of unemployed people and the number of employees. For such limitations, see the League of Nations (1935).

${ }^{16}$ It is necessary to consider the existence of different ascertainment methodologies of GDP between
} 
considered countries, 1928, as well as 2007, represent the last years of expansion. On the other hand, 1929, as well as 2008, represent the years when the crisis became explicit and for this reason they are considered the base periods. Over the following years, these countries began to face profound crises. In fact, it can be observed that in both moments there was a sudden and violent fall of GDP of the countries of the region.

The data shown in Table 1 indicate that, in general, while in the Great Depression of the 1930's the central countries were the most impacted in terms of reduction of production levels, in the recent crisis, the periphery countries were the most harmed. Once more, this reflects the existing inequalities among the countries that are part of the European monetary union. For instance, while the GDP of Germany fell 10\% and that of Greece increased 7\% between 1929 and 1933, the GDP of Germany fell 10\% and that of Greece decreased 30\% between 2008 and 2012. ${ }^{17}$

The same happened in the cases of Italy and the United Kingdom. Despite being central countries, the impact of the recent crisis was comparable to that observed in peripheral countries. In fact, for having one of the highest public debts in Europe, Italy was forced to implement a deflationary adjustment similar to that carried out by countries such as Spain, Greece, Ireland, and Portugal. On the other hand, the performance of the United Kingdom is due to the impact of the crisis on the important financial sector of the country, as well as to the resistance of the conservative government to adopt more flexible economic policies in order to face the retraction of private consumption and investment. Not even the devaluation of the pound was able to encourage recovery through an increase of exports as a consequence of the situation of other European countries, which are British main trade partners.

Table 1 also shows that, in the case of the Great Depression of the 1930's, the fall of economic activity continued up to 1932, starting a recovery trajectory since then. Nevertheless, the strength of this process was related to the moment when the countries abandoned the gold standard and began to adopt countercyclical policies. It occurred earlier in the case of Germany, England, and Sweden and later in the case of France and Italy. In the case of the recent crisis, the fall of GDP occurred after 2009. This movement is closely related to the progressive stiffening of fiscal adjustments carried out in a context characterized by the contraction of ex-

both considered periods. The calculation of the GDP of each country in the period of Great Depression of the 1930's was based on estimates grounded on available registrations about the production of different sectors of economy, in view of inexistence of the required rules and norms to assure the standardization of National Accounts and, more specifically, from calculation of total wealth produced by different countries in a certain period. More emphatic initiatives in this regard occurred after World War II, with the creation of multilateral institutions, such as the United Nations and the International Monetary Fund. Regarding this matter, see Maddison (1995).

${ }^{17}$ Differently from that context, the most recent crisis occurred in an environment where social protection systems are available. However, it must be observed that the institutionality of Welfare State in European countries has different sophistication levels, being less comprehensive and inclusive in the periphery countries (Wolf, 2015). 
Table 1: Gross Domestic Product (selected countries)

$(1929=100$ and $2008=100)-1928$ to 1934 and 2007 to 2013

\begin{tabular}{|c|c|c|c|c|c|c|c|c|}
\hline \multicolumn{9}{|c|}{ Great Depression } \\
\hline & & 1928 & 1929 & 1930 & 1931 & 1932 & 1933 & 1934 \\
\hline \multirow{5}{*}{ 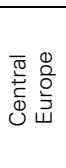 } & France & 94 & 100 & 97 & 91 & 85 & 91 & 91 \\
\hline & Germany & 100 & 100 & 99 & 91 & 84 & 90 & 98 \\
\hline & Italy & 97 & 100 & 95 & 95 & 98 & 97 & 97 \\
\hline & Sweden & 93 & 100 & 104 & 103 & 100 & 103 & 111 \\
\hline & United Kingdom & 97 & 100 & 99 & 94 & 95 & 98 & 104 \\
\hline \multirow{4}{*}{ 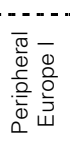 } & Greece- & $\overline{94}$ & 100 & 98 & 94 & 101 & 107 & 110 \\
\hline & Ireland & 97 & 100 & 102 & 105 & 103 & 100 & 103 \\
\hline & Portugal & 90 & 100 & 99 & 104 & 106 & 113 & 118 \\
\hline & Spain & 93 & 100 & 97 & 94 & 96 & 94 & 98 \\
\hline \multicolumn{9}{|c|}{ European Crisis } \\
\hline & & 2007 & 2008 & 2009 & 2010 & 2011 & 2012 & 2013 \\
\hline \multirow{5}{*}{ 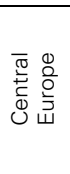 } & France & 93 & 100 & 92 & 89 & 95 & 88 & 91 \\
\hline & Germany & 92 & 100 & 90 & 89 & 96 & 90 & 93 \\
\hline & Italy & 94 & 100 & 89 & 87 & 91 & 82 & 83 \\
\hline & Sweden & 98 & 100 & 82 & 93 & 106 & 102 & 107 \\
\hline & United Kingdom & 109 & 100 & 80 & 80 & 84 & 84 & 82 \\
\hline \multirow{4}{*}{ 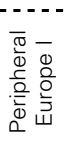 } & Greece & 93 & $100^{-1}$ & 92 & -83 & 81 & 70 & -69 \\
\hline & Ireland & 95 & 100 & 89 & 84 & 89 & 83 & 86 \\
\hline & Portugal & 93 & 100 & 92 & 89 & 92 & 83 & 84 \\
\hline & Spain & 92 & 100 & 91 & 87 & 91 & 83 & 84 \\
\hline
\end{tabular}

Source: Maddison (2008) and IMF. Elaborated by the authors.

Note: Since there is no information available for all countries that today are part of the EU, representative countries from the center and the periphery of the bloc were selected.

penses of the private sector, and which were ultimately a requirement of the market, sanctioned by the European institutions, to the countries of the region.

Concerning international trade, Table 2 shows the behavior of export and import indexes, also in both periods considered. Although in both moments there was a remarkable fall in trade relations due to the reduction of the level of activity in the region as whole, this fall was much greater in the context of the Great Depression compared to the period of the recent crisis. In the first case, the exports and imports corresponded to almost $40 \%$ of the values observed in 1929 , while in the second they corresponded to approximately $80 \%$ of the observed values in 2008. This is mostly a consequence of the fact that, at that time, European countries appealed to the devaluation of exchange rates and to the adoption of protectionist commercial policies after abandoning the gold standard. ${ }^{18}$ Moreover, the deflationary adjustment carried out by the peripheral countries certainly produced an expressive improvement in their respective trade balances.

\footnotetext{
${ }^{18}$ Currently, the adoption of such measures is not possible, even in the case of the trade between European countries, which is responsible for the greatest part of international trade of EU countries in general and of Eurozone in particular, as a result of the rules of common market and limits imposed by the adoption of the Euro.
} 
Table 2: Exports $(\mathrm{X})$ and Imports $(\mathrm{M})$ (selected countries)

$(1929=100$ and $2008=100)-1928$ to 1933 and 2007 to 2012

\begin{tabular}{|c|c|c|c|c|c|c|c|c|c|c|c|c|c|}
\hline \multicolumn{14}{|c|}{ Great Depression } \\
\hline & & \multicolumn{2}{|c|}{1928} & \multicolumn{2}{|c|}{1929} & \multicolumn{2}{|c|}{1930} & \multicolumn{2}{|c|}{1931} & \multicolumn{2}{|c|}{1932} & \multicolumn{2}{|c|}{1933} \\
\hline \multirow{4}{*}{ 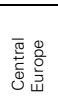 } & France & 104 & 92 & 100 & 100 & 85 & 90 & 61 & 72 & 39 & 51 & 37 & 49 \\
\hline & Germany & 91 & 104 & 100 & 100 & 89 & 77 & 71 & 50 & 42 & 35 & 36 & 31 \\
\hline & Italy & 98 & 103 & 100 & 100 & 80 & 80 & 66 & 54 & 45 & 38 & 39 & 34 \\
\hline & Sweden & 87 & 96 & 100 & 100 & 86 & 93 & 57 & 75 & 36 & 45 & 38 & 39 \\
\hline \multirow{5}{*}{ 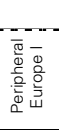 } & United Kingdom & 99 & 97 & 100 & 100 & 78 & 86 & 50 & 66 & 36 & 42. & 34 & 38 \\
\hline & Greece & 87 & $\overline{9} \overline{4}$ & 100 & 100 & $\overline{8}$ & $\overline{7} \overline{9}$ & $\overline{60}$ & 66 & 38 & $\overline{38}$ & $3 \overline{3}$ & 28 \\
\hline & Ireland & 97 & 98 & 100 & 100 & 95 & 92 & 72 & 77 & 40 & 77 & 28 & 50 \\
\hline & Portugal & 96 & 106 & 100 & 100 & 88 & 96 & 70 & 62 & 53 & 48 & 51 & 61 \\
\hline & Spain & 100 & 110 & 100 & 100 & 109 & 89 & 46 & 43 & 35 & 36 & 32 & 31 \\
\hline \multicolumn{14}{|c|}{ European Crisis } \\
\hline & & \multicolumn{2}{|c|}{2007} & \multicolumn{2}{|c|}{2008} & & & \multicolumn{2}{|c|}{2010} & \multicolumn{2}{|c|}{2011} & \multicolumn{2}{|c|}{2012} \\
\hline \multirow{4}{*}{ 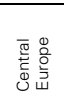 } & France & 91 & 88 & 100 & 100 & 78 & 78 & 86 & 86 & 98 & 101 & 94 & 95 \\
\hline & Germany & 91 & 88 & 100 & 100 & 77 & 78 & 87 & 89 & 101 & 105 & 97 & 97 \\
\hline & Italy & 92 & 91 & 100 & 100 & 75 & 74 & 82 & 87 & 97 & 100 & 92 & 87 \\
\hline & Sweden & 92 & 90 & 100 & 100 & 71 & 71 & 86 & 88 & 102 & 104 & 94 & 96 \\
\hline \multirow{5}{*}{ 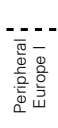 } & United Kingdom & 96 & 98 & 100 & 100 & -177 & 76 & 89 & 89 & 103 & 100 & 105 & 109 \\
\hline & Spain & 91 & $9 \overline{3}$ & 100 & 100 & 80 & 69 & 88 & 75 & 107 & 87 & 102 & 78 \\
\hline & Greece & 92 & 85 & 100 & 100 & 79 & 75 & 85 & 72 & 124 & 68 & 138 & 70 \\
\hline & Ireland & 96 & 102 & 100 & 100 & 92 & 74 & 93 & 71 & 100 & 79 & 93 & 74 \\
\hline & Spain & 91 & 93 & 100 & 100 & 80 & 69 & 88 & 75 & 107 & 87 & 102 & 78 \\
\hline
\end{tabular}

Source: League of Nations (1935) and UNCTAD. Elaborated by the authors.

In order to avoid the deflationary adjustment, an intense cooperation system among superavit and deficit countries of the region, led by a hegemonic center that is able to assume the functions of purchaser and lender of last resort would be required. In this regard, similarly to England after World War I and the United States after World War II, Germany has an important role to play in Europe with regard to aforementioned functions in the scale required to overcome the crisis. However, this would require a limit to the high trade superavits that Germany maintains with regard to the countries of the European periphery, something that Germans do not accept.

Such initiative would make a great contribution to a less asymmetric way to adjust the Eurozone economies. An alternative to it would be, for instance, the implementation of an internal European commercial policy that is functional for the necessities of the most fragile economies of the bloc, allowing them to reintroduce the control over the flows of goods and services through an increase in tariff barriers with regard to less fragile economies. It would require an amendment of the treaties in force through a specific legislative process, although the European institutions explicitly acknowledging that the process of opening national borders must consider the extent of the effort that the economies must bear or, in other words, the existing differences among them in regard to their degree of development. By fostering the favorable adjustment of relative prices, this type of policy would have the same effect of an exchange rate devaluation, with the advantage of affecting the trade relations among European countries. ${ }^{19}$ This type of measure

\footnotetext{
${ }^{19}$ It must be highlighted that this kind of commercial policy in a project of regional integration was defended by ECLA in the second half of 20th century. For details, see Amado and Mollo (2004).
} 
could be followed by actions of supranational institutions aimed at transforming the productive structures and at increasing the competitiveness of the weakest economies of the region. ${ }^{20}$

It is interesting to register that, although insufficient to avoid the deflationary adjustment, the state interventions immediately following the outbreak of the recent crisis were an important differential compared to the Great Depression, preventing it from being even deeper. The imbalances in the public accounts of most countries of the European periphery resulted (to a great extent) from the "socialization of private losses" and from the attempt to avoid a significant fall of demand. Except for Greece, where there was consistent evidence of excesses, the public accounts of the periphery countries were relatively balanced up to the outbreak of the crisis in 2008. Portugal had levels of public deficit and public debt comparable to those of the main central countries (around -3\% and 60\% of GDP, respectively), and the levels of deficit and debt of Spain and Ireland were among the smallest of the EU (around 1\% and $40 \%$, respectively).

Through the support of the level of output, income and employment, state intervention also contributed to accommodate the relevant deleverage process of the private sector. In fact, after the excesses committed in the period prior to the outbreak of the crisis, which was characterized by abundant and cheap money, financial institutions, families, and companies began a process of reducing their degree of indebtedness. Consequently, in all periphery countries, the private debt considerably increased up to 2008 , decelerating, stabilizing, or even being reduced ever since. On the other hand, the public debt had the inverse behavior: it remained relatively stable up to 2008 , considerably increasing in the following years.

Graph 2 displays this process. It shows, on the one hand, the variation (in percentage points) of the public debt/GDP ratio between 2008 and 2012 for the 27 countries that were part of the EU up to 2012, and, on the other hand, the ratio between: a) the variation (in percentage points) of the private debt/GDP ratio between 2008 and 2012; and b) the variation (in percentage points) of the private debt/GDP ratio between 2004 and 2008; considering the countries whose data were available. Except for a few economies of the region, it can be observed that the public debt/GDP ratio increased substantially between 2008 and 2012, while the indicator related to private debt was inferior to the unit, indicating a deceleration of the growth of private debt/GSP, or below zero, indicating a reduction of the specified ratio between 2004-2008 and 2008-2012. For instance, in Spain, the public debt/GDP ratio increased 46 percentage points of GDP between 2008 and 2012 , while the calculated indicator of private debt was -0.3 , the quotient between the fall of 15.1 percentage points of the private debt/GDP ratio between 2008 and 2012 and the increase of 57.5 percentage points of this same ratio between 2004

\footnotetext{
${ }^{20}$ In view of the fragmentation of productive chains that occurred throughout the regional integration process, with the stages of smaller added value restricted to the less developed economies of bloc, this policy tends to make intraregional exports more expensive. Nevertheless, this expensiveness can be neutralized by making different stages of the productive process cheaper through an increase in productivity, for example.
} 
and 2008. Germany was the only country among those of the Eurozone whose data of private debt/GDP ratio were available, which began to show a reduction of this ratio after 2004; while the public debt increased 15 percentage points within the aforementioned time, the private debt/GDP ratio varied -4.6 percentage points between 2004 and 2008 and $-9.7 \%$ between 2008 and 2012. ${ }^{21}$

The fiscal adjustment carried out by the peripheral countries was not effectively able to avoid the increase of public indebtedness due to the impact of these measures on the level of activity and, consequently, on the receipts of the governments of those countries. Moreover, it must be observed that while the countercyclical state intervention has occurred in the context of the recent crisis, compared to that of the Great Depression, it can be claimed that it was too late and also insufficient to avoid exceptional falls of GDP levels in the different countries of the region. Additionally, although cooperation among countries has been greater now than before, it was also absolutely insufficient to handle with the disruptive effects caused by the logic of operation of increasingly liberalized and deregulated markets in a context marked by the exceptional reduction of autonomy over economic policy of the economies of the Eurozone.

Graph 2: European Union countries' public debt and private debt behaviors (selected indicators)

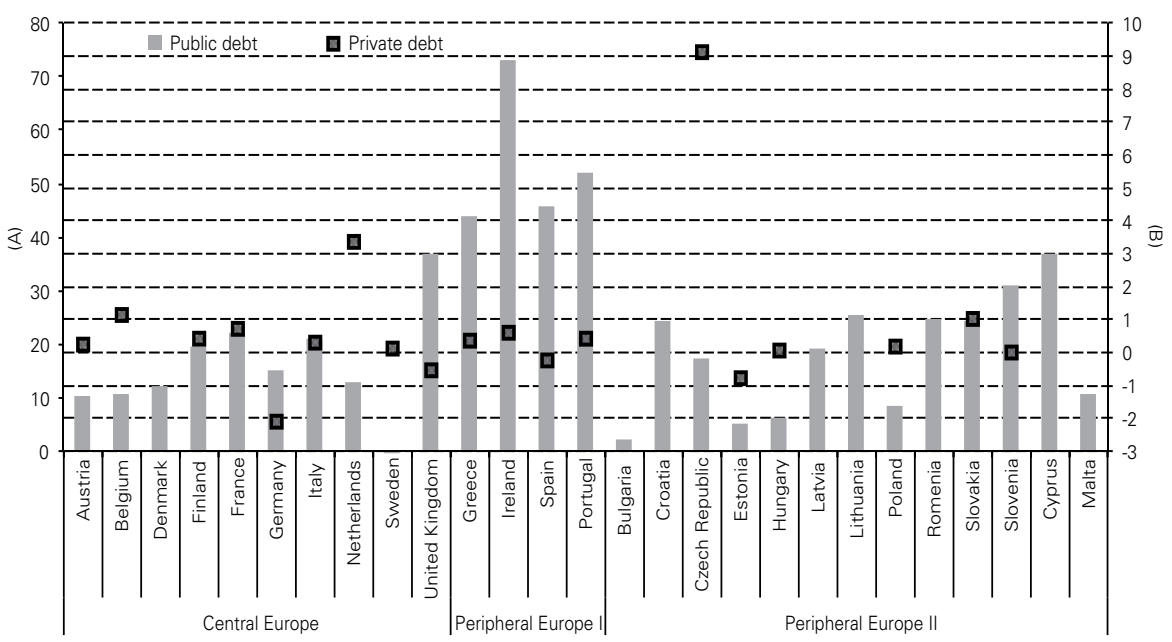

Source: IMF e OECD. Elaborated by the authors.

Note: Left axis (A): change in percentage points in the public debt/GDP between 2008 and 2012; right axis (B): ratio between change (in percentage points) of the ratio between Private Debt/GDP between 2008 and 2012 and between 2004 and 2008.

\footnotetext{
${ }^{21}$ Among the Eurozone countries where data on private debt and GDP are available, Germany was the only one to have a negative variation (in percentage points) of this rate between 2004 and 2008 . Therefore, in the case of this country, the indicator of private debt was submitted with the numerator of the ratio in module.
} 
Finally, Table 3 shows the evolution of public debt in both periods. The public debt considerably increased after 1929, during the Great Depression, and after 2008, during the current European Crisis, in almost all considered countries, either because the governments of those countries increased their expenses or because their receipts were reduced due to the fall of production. It is true that governments of some of the countries attempted to reduce their expenses and to increase their receipts, but the impact of these measures on output, income, and employment levels made it impracticable to reduce the debt. The case of peripheral countries in the current European crisis is emblematic. These countries were forced to implement strict fiscal adjustments in order to be able to apply for the financial assistance mechanisms. However, this did not prevent the deterioration of public accounts from the point of view of indebtedness, due to a sharp retraction of the level of activity and the high burden of interest levied over the debt. Between 2008 and 2013 , the public debt increased by $120 \%$ in Spain, $21 \%$ in Greece, $171 \%$ in Ireland, and $71 \%$ in Portugal. Greece had the greatest public debt related to GDP before the crisis among all countries of the EU $103.1 \%$ compared to $23.9 \%$ of Ireland, $35.5 \%$ of Spain, and $68.4 \%$ of Portugal.

Table 3: Public debt (selected countries)

$(1929=100$ and $2008=100)-1928$ to 1933 and 2007 to 2012

\begin{tabular}{|c|c|c|c|c|c|c|c|c|}
\hline & \multicolumn{8}{|c|}{ Great Depression } \\
\hline & & 1928 & 1929 & 1930 & 1931 & 1932 & 1933 & 1934 \\
\hline \multirow{4}{*}{ 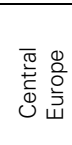 } & France & 100 & - & 103 & 103 & 98 & - & - \\
\hline & Germany & 88 & 100 & 116 & 135 & 135 & 137 & 138 \\
\hline & Italy & 99 & 100 & 101 & 105 & 109 & 111 & 117 \\
\hline & Sweden & 99 & 100 & 98 & 101 & 117 & 129 & 128 \\
\hline \multirow{7}{*}{ 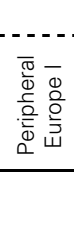 } & United Kingdom & 100 & 100 & 100 & 100 & 100 & 103 & 105 \\
\hline & Greece & 96 & 100 & 101 & 108 & $\overline{113}$ & 113 & 113 \\
\hline & Ireland & 94 & 100 & 107 & 122 & 132 & 130 & 206 \\
\hline & Portugal & 102 & 100 & - & - & 72 & 73 & 72 \\
\hline & Spain & 93 & 100 & 100 & 99 & 102 & 105 & 104 \\
\hline & \multicolumn{8}{|c|}{ Euopean Crisis } \\
\hline & & 2007 & 2008 & 2009 & 2010 & 2011 & 2012 & 2013 \\
\hline \multirow{5}{*}{ 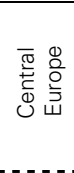 } & France & 92 & 100 & 113 & 120 & 129 & 138 & 144 \\
\hline & Germany & 96 & 100 & 107 & 125 & 127 & 132 & 131 \\
\hline & Italy & 96 & 100 & 106 & 111 & 114 & 119 & 124 \\
\hline & Sweden & 101 & 100 & 106 & 106 & 108 & 110 & 120 \\
\hline & United Kingdom & 82 & 100 & 124 & 151 & 168 & 181 & 190 \\
\hline \multirow{4}{*}{ 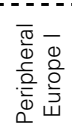 } & Greece & $9 \overline{1}$ & 100 & 114 & 125 & 135 & 115 & 121 \\
\hline & Ireland & 59 & 100 & 131 & 181 & 239 & 264 & 271 \\
\hline & Portugal & 94 & 100 & 114 & 135 & 153 & 166 & 171 \\
\hline & Spain & 87 & 100 & 129 & 148 & 169 & 203 & 220 \\
\hline
\end{tabular}

Source: League of Nations (1935). Elaborated by the authors. 


\section{CONCLUSION}

This paper demonstrated that, as the British gold standard, the institutionality of the Euro induces the deflationary adjustment of participating economies during periods characterized by adversities. In this sense, as in the case of the Great Depression in 1930's, overcoming the recent European crisis requires the adoption of countercyclical economic policies, as well as an increase in cooperation among the countries of the region. Nevertheless, the measures imposed by the markets and sanctioned by the European institutions for the peripheral countries of the region ignore the true nature of the problems faced by the economies that integrate the monetary union in Europe.

Therefore, the overcome of the crisis in the region requires the reform of the institutional arrangement that supports the Euro. This means that, in the terms of Minsky (1986), the European Central Bank must operate as a "Big Bank" and the national governments as "Big Governments". However, without a cooperation system among the countries of the region, led by the regional hegemonic center, this strategy would become impracticable, especially with regard to the countercyclical action of national governments.

The monetary union was not followed by a fiscal arrangement able to assure transferences of resources among European countries if needed. Currently, the budget of the EU is rather modest and must always be kept balanced, as it is not allowed to obtain resources in the market by issuing debt bonds. This prevents it from operating as a stabilization instrument in countries with difficulties, functioning in a countercyclical way. But a process of this kind is hardly feasible without a high degree of political integration between European countries and, consequently, without the constitution of a "European federation".

Regarding the impossibility of adjusting the nominal exchange rate within the institutionality landmarks of the Euro, on one hand, and the importance of interregional trade to countries of the Eurozone, on the other, the sustained recovery of economies of the region could occur upon an agreement between superavit and deficit countries led by the regional hegemonic country, which can include other measures such as the adoption of commercial policies that favor the countries in distress.

The measures oriented towards the implementation of a deflationary adjustment imposed by the markets and sanctioned by the European authorities ignore the true nature of the problems faced by the countries of the monetary union and thus make it impossible to implement effective actions in order to overcome them. The deflationary adjustment is a consequence of a regional integration project that failed to include adequate cooperation measures among member countries, thus betraying its original intentions.

\section{REFERENCES}

ARESTIS, Philip; SAWYER, Malcolm (2011). “The design faults of the economic and monetary union”. Journal of Contemporary European Studies, 19 (1): 21- 32.

AMADO, Adriana. M.; MOLLO, Maria de Lourdes R. (2004). “Ortodoxia e heterodoxia na discussão 
sobre integração regional: a origem do pensamento da CEPAL e seus desenvolvimentos posteriors”. Estudos Econômicos, São Paulo, 34 (1): 129-156.

BELLUZZO, Luiz G. "Prefácio". In: CINTRA, Marcos Antônio M.; MARTINS, Aline Regina A. (eds.) (2013). As Transformações no Sistema Monetário Internacional. Brasília: IPEA.

BRESSER-PEREIRA, Luiz Carlos; ROSSI, Pedro (2014). "Sovereignty, the exchange rates, collective deceit, and the euro crisis". European Association for Evolutionary Political Economy Annual Conference, Chipre.

CHICK, Victoria; DOW, Sheila C. (1988). "A post-keynesian perspective on the relation between banking and regional development”. In: ARESTIS, P. (ed.). Post-keynesian monetary economics. Cheltenham, UK: Edward Elgar.

DE GRAUWE, Paul (2011). “The governance of a fragile eurozone”. Economic Policy, CEPS Working Documents n. 346.

DOW, Sheila (1982). "The regional composition of the money multiplier process". Scottish Journal of Political Economy, 29 (1): p. 22-44.

DOW, Sheila (1987a). "The treatment of money in regional economics". Journal of Regional Science, 27 (1): 13-24.

DOW, Sheila (1987b). "Money and regional development". Studies in Political Economy, 23: 73-94.

EICHENGREEN, Barry J. (2000). A globalização do Capital: Uma História do Sistema Monetário Internacional. São Paulo, SP: Editora 34.

FREITAS, Maria Cristina P. (2011). "A crise na área do euro". Boletim de Economia n.10: 21-39.

FUNDO MONETÁRIO INTERNACIONAL. World Economic Outlook Databases: base de dados. Disponível em: <http://www.imf.org/external/ns/cs.aspx?id=28>

KENWOOD, George; LOUGHEED, Alan (1992). The Growth of the International Economy 18201990: an introductory text. 3. ed. New York, US: Routledge.

KEYNES, John M. (1936 [2007]). A Teoria Geral so Emprego, do Juro e da Moeda. São Paulo, SP: Atlas.

KEYNES, John M. (1930 [1984]). “Considerações sobre o padrão ouro” (1930). In: SZMERECSÁNYI, Tamás (org). Keynes. São Paulo: Ática.

KEYNES, John M. (1925). “The economic consequences of Mr. Churchill”. In: JOHNSON, E.; MOGGRIDGE, D. (eds) (1978). The Collected Writings of John Maynard Keynes, vol. 9. Royal Economic Society.

KINDLEBERGER, Charles (1989). Manias, Panics, and Crashes: A History of Financial Crises. Revised edition. New York, US: Basic Books.

KINDLEBERGER, Charles (1986). The World in Depression: 1929-1939. Revised and enlarged edition. Berkeley, US: University of California.

LIGA DAS NAÇÕES (1935). Statistical Yearbook of the League of Nations. Genebra, CH: Series of League of Nations Publications.

MADDISON, Angus (1995). Monitoring the World Economy 1820-1992. Paris: OECD, Development Centre.

MADDISON, Angus (2008). "Historical statistics of the world economy: 1-2008 AD”. In: MADDISON, Angus. Original homepage Angus Maddison. Disponível em: $<$ http://www.ggdc.net/maddison/oriindex.htm>. Acesso em: mar. 2014.

MAZZUCCHELLI, Frederico M. (2009). Os Anos de Chumbo: Economia e Política Internacional no Entreguerras. Campinas, SP: FACAMP.

MEDEIROS, Carlos A.; SERRANO, Franklin (1999). "Padrões monetários internacionais e crescimento”. In: FIORI, José L. (ed.). Estados e Moedas no Desenvolvimento das Nações. Petrópolis, RJ: Vozes.

MINSKY, H. (1986). Stabilizing an Unstable Economy. New Haven, US: Yale University Press.

MISSIO, Fabricio José; JAYME JUNIOR, Frederico G.; OREIRO, José Luis C. (2015). "The structuralist tradition in economics: methodological and macroeconomics aspects". Revista de Economia Política, 35: 247-266.

OLIVEIRA, Giuliano C.; DEOS, Simone S.; WOLF, Paulo José W. (2012). “A crise europeia e os limites 
do ajuste deflacionário". In: MODENESI, A. M. et al. (eds.). Dossiê da Crise: volume três. Rio de Janeiro, RJ: Ed. Elsevier.

ORGANIZAÇÃO DAS NAÇÕES UNIDADES PARA O COMÉRCIO E O DESENVOLVIMENTO. Statistics: base de dados. Disponível em: <http://unctad.org/en/Pages/Statistics.aspx>

ORGANIZAÇÃO PARA A COOPERAÇÃO E O DESENVOLVIMENTO ECONÔMICO. StatExtracts: base de dados. Disponível em: <http://www.oecd.org/statistics/>

POLANYI, Karl (1944 [2000]). A Grande Transformação: As Origens da Nossa Época. 2. ed. Rio de Janeiro, RJ: Campus.

RAIMUNDO, Lício C. (2011). “As raízes históricas da crise europeia”. Carta Social e do Trabalho n.15, Campinas: 2-17.

TRIFFIN, Robert (1972). O Sistema Monetário Internacional. Rio de Janeiro: Expressão e Cultura.

WOLF, Paulo José W. (2015). Os Estados de Bem-Estar Social da Europa Ocidental: Tipologias, Fundamentos e Evidências. Dissertação (mestrado em economia) - Instituto de Economia da Unicamp, Campinas/SP. 